Check for updates

Cite this: RSC Adv., 2017, 7, 21997

\title{
Properties of a flavonol-based photoCORM in aqueous buffered solutions: influence of metal ions, surfactants and proteins on visible light- induced $\mathrm{CO}$ release $\uparrow$
}

\begin{abstract}
Marina Popova, ${ }^{a}$ Tatiana Soboleva, ${ }^{a}$ Atta M. Arif ${ }^{b}$ and Lisa M. Berreau (iD *a
The properties of the extended flavonol 3-hydroxy-2-phenyl-benzo[g]chromen-4-one (2a) in DMSO : aqueous buffer solutions at $\mathrm{pH}=7.4$, including in the presence of metal ions, surfactants and serum albumin proteins, have been examined. Absorption and emission spectral studies of $2 a$ in $1: 1$ DMSO : PBS buffer $(\mathrm{pH}=7.4)$ indicate that a mixture of neutral and anionic forms of the flavonol are present. Notably, in 1 : 1 DMSO : TRIS buffer $(\mathrm{pH}=7.4)$ only the neutral form of the flavonol is present. These results indicate that the nature of the buffer influences the acid/base equilibrium properties of $2 a$. Introduction of a $\mathrm{Zn}(॥)$ complex of $2 \mathrm{a}^{-}$to a $1: 1 \mathrm{DMSO}$ : aqueous buffer (TRIS or PBS, $\mathrm{pH}=7.4$ ) solution produces absorption and emission spectral features consistent with the presence of a mixture of neutral $2 a$ along with $\mathrm{Zn}(॥)$-coordinated or free $2 \mathrm{a}^{-}$. The nature of the anionic species present depends on the buffer composition. PBS buffered solutions $(\mathrm{pH}=7.4)$ containing the surfactants CTAB or SDS enable $2 a$ to be solubilized at a much lower percentage of DMSO (3.3-4.0\%). Solutions containing the cationic surfactant CTAB include a mixture of $2 a$ and $2 a^{-}$whereas only the neutral flavonol is present in SDScontaining buffered solution. Compound $2 a$ is also solubilized in TRIS buffer solutions at low cocentrations of DMSO $(3.3 \%, \mathrm{pH}=7.4)$ in the presence of serum albumin proteins. Stern-Volmer analysis of the quenching of the inherent protein fluorescence indicates static binding of $2 a$ to the proteins. The binding constant for this interaction is lower than that found for naturally-occurring flavonols (quercetin or morin) or 3-hydroxyflavone. Compound 2 a binds to Site I of bovine and human serum albumin proteins as indicated by competition studies with warfarin and ibuprofen, as well as by docking investigations. The quantum yield for $\mathrm{CO}$ release from $2 \mathrm{a}\left(\lambda_{\mathrm{irr}}=419 \mathrm{~nm}\right)$ under aqueous conditions ranges from 0.0006 (3) when the compound is bound to bovine serum albumin to $0.017(1)$ when present as a zinc complex in a 1:1 DMSO : $\mathrm{H}_{2} \mathrm{O}$ solution. Overall, the results of these studies demonstrate that $2 \mathrm{a}$ is a predictable visible light-induced $\mathrm{CO}$ release compound under a variety of aqueous conditions, including in the presence of proteins.
\end{abstract}

Received 4th March 2017

Accepted 10th April 2017

DOI: $10.1039 / \mathrm{c} 7 \mathrm{ra02653f}$

rsc.li/rsc-advances

\section{Introduction}

Carbon monoxide (CO) is generated in humans via the oxidative degradation of heme, which is catalyzed by heme oxygenase enzymes. ${ }^{1}$ The discovery of beneficial health effects associated with the delivery of small amounts of CO, including antiinflammatory, anti-apoptotic, and anti-proliferative effects, as well as the promotion of vasodilation and protection of tissues against reperfusion injury, has led to investigations of the

${ }^{a}$ Department of Chemistry \& Biochemistry, Utah State University, 0300 Old Main Hill, Logan, UT 84322-0300, USA. E-mail: lisa.berreau@usu.edu

${ }^{b}$ Department of Chemistry, University of Utah, 315 S. 1400 E., Salt Lake City, UT 84112-0850, USA

$\dagger$ Electronic supplementary information (ESI) available. CCDC 1523782. For ESI and crystallographic data in CIF or other electronic format see DOI: 10.1039/c7ra02653f possible use of $\mathrm{CO}$ as a therapeutic. ${ }^{2-8}$ Several clinical trials are currently in progress involving the use of inhaled carbon monoxide. ${ }^{9-14}$ A challenge in using inhaled $\mathrm{CO}$ as a therapeutic is that it does not enable the delivery of controlled amounts of CO to specific targets and diffusion into tissues is unpredictable. As an approach toward introducing controlled amounts of $\mathrm{CO}$, several research labs have worked on the development of CO-releasing molecules (CORMs). ${ }^{15,16}$ The most widely investigated CORMs to date are metal carbonyl complexes, ${ }^{17}$ with CORM-1 and CORM-3 (Fig. 1(top)) having been employed in a variety of biological investigations. Metal carbonyl-based CORMs release CO either spontaneously via ligand exchange, or via triggering with light (photoCORMs), ${ }^{18-25}$ enzyme activity, ${ }^{26-29}$ or magnetic heating ${ }^{30-32}$ (Fig. 1). A drawback of the use of metal carbonyl complexes as CORMs is the possible (or perceived) toxicity of the residual low-valent metal fragment 
<smiles></smiles>

CORM-1

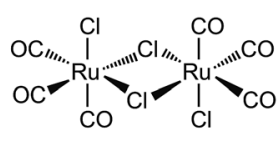

CORM-2

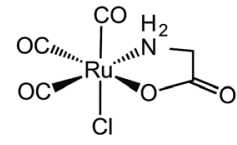

CORM-3

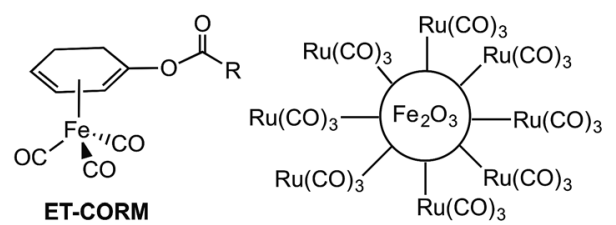

$\mathrm{R}=-\mathrm{CH}_{3},{ }^{\mathrm{B}} \mathrm{Bu}$

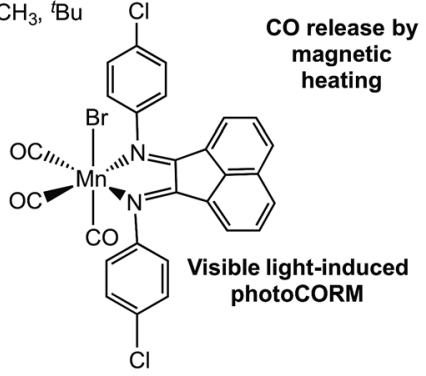

Fig. 1 Examples of metal carbonyl-based CORMs. ${ }^{17,20,28,30}$

remaining following $\mathrm{CO}$ release. Additionally, little is currently known in terms of the reactivity of metal carbonyl-based CORMs with other biomolecules. It was only after CORM-3 had been used in a several biological studies that the active form for CO-release in vivo was determined to likely be a protein-bound $\mathrm{Ru}(\mathrm{CO})_{2}$ species. ${ }^{33,34}$ In general, although many metal carbonyl species have been demonstrated to be CORMs and to enable $\mathrm{CO}$ release both in vitro and in cellular environments, very few have been studied with regard to their interactions with biological molecules, such as proteins. ${ }^{35,36}$ These interactions could dramatically affect the CO-release reactivity.

Metal-free CORMs $^{37,38}$ and photoCORMs ${ }^{39-42}$ (Fig. 2) have recently emerged as alternatives to metal carbonyl-based COreleasing molecules. Of the structural frameworks reported thus far for metal-free photoCORMs, the BODIPY and extended flavonol motifs (Fig. 2) are notable in that they can be tuned to enable the use of low energy visible light $(>575 \mathrm{~nm})$ to induce CO release, which is important for use in biological environments. The CO release unit in $\mathbf{1 a / 1 \mathbf { b }}$ is a carboxyl moiety whereas the extended flavonol motif in $\mathbf{2 a - d}$ contains a pyrone ring that is similar to naturally occurring flavonols (e.g., quercetin), which are known to undergo enzyme-catalyzed $\mathrm{CO}$ release. ${ }^{43}$ The visible light-induced $\mathrm{CO}$ release reaction involving 1a or 1b proceeds in high yield (87-92\%) only under anaerobic conditions, with the yield of $\mathrm{CO}$ under aerobic conditions dropping to $42-44 \%{ }^{39}$ Visible light-induced carbon monoxide release from $2 \mathbf{a}-\mathbf{c}$ requires the presence of $\mathrm{O}_{2}$ for a quantitative, dioxygenase-type reaction to produce an $O$-benzoylsalicylic acid product (3a, Scheme 1). Complex 2d exhibits both aerobic and anaerobic visible light-induced quantitative CO release reactivity. ${ }^{42}$

Development of an understanding of the properties of metalfree CO-releasing photoCORM frameworks in aqueous buffered solutions and in the presence of biomolecules is essential
Click-and-release CORMs

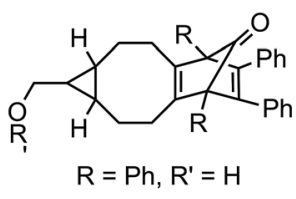

PhotoCORMs
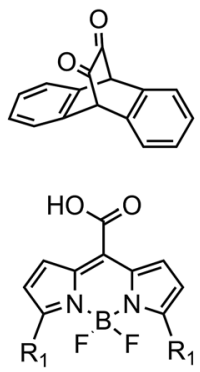

1a: $\mathrm{R}_{1}=-\mathrm{CH}_{3}$

1b: $\mathrm{R}_{1}=-\mathrm{CH}=\mathrm{CH}-\mathrm{C}_{6} \mathrm{H}_{4}-\mathrm{O}\left(\mathrm{CH}_{2} \mathrm{CH}_{2} \mathrm{O}\right)_{3} \mathrm{CH}_{3}$<smiles>O=C1C=CC2=C(C(=O)O)c3ccc(O)cc3OC2C1</smiles><smiles>[X]C1=C(O)C(c2ccc([R])cc2)=Cc2cc3ccccc3cc2O1</smiles>

2a: $X=O, R=H$ 2b: $X=O, R=\mathrm{NEt}_{2}$ 2c: $X=S, R=H$ 2d: $\mathrm{X}=\mathrm{S}, \mathrm{R}=\mathrm{NEt}_{2}$

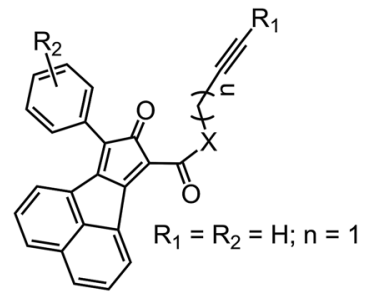

Fig. 2 Metal-free CORMs and photoCORMs reported to date. ${ }^{36-41}$

toward the further development of these motifs as potential biological tools and therapeutics. Klán and coworkers have reported that at $\mathrm{pH}=7.4$ in PBS buffer, $\mathbf{1 a}$ and $\mathbf{1 b}$ exist as monoanions, with a deprotonated carboxyl group $\left(\mathrm{p} K_{\mathrm{a}}=3.0 \pm 0.2\right) \cdot{ }^{39}$ Under anaerobic conditions in PBS $(\mathrm{pH}=7.4)$ visible lightinduced $\mathrm{CO}$ release occurs from $\mathbf{1 a}$ and $\mathbf{1 b}$ with quantum yields of $1.2(4) \times 10^{-4}$ and $1.2(4) \times 10^{-5}$, respectively. It is currently unknown how a biological environment, including the presence of proteins, will affect these values. The organic products in these $\mathrm{CO}$ release reactions also remain only partially characterized.

We have previously reported the visible light-induced CO release reactivity of $2 \mathbf{a}^{-} \mathbf{d}^{42}$ and zinc complexes of these flavonols in organic solvent (acetonitrile). ${ }^{44}$ All exhibit quantitative CO release under aerobic conditions. The quantum yields for these reactions are significantly affected by the presence of a neutral versus anionic form of the flavonol. Specifically, for 2a the quantum yield for $\mathrm{CO}$ release in $\mathrm{CH}_{3} \mathrm{CN}$ is 0.007 (3) whereas for zinc complex of $2 \mathrm{a}^{-}$it is $0.651(2)$, a $>90$-fold increase. ${ }^{42,44}$ Experimental and computational studies of 3-hydroxyflavone (3$\mathrm{HflH}$ ) indicate that the $\mathrm{p} K_{\mathrm{a}}$ for this compound is $\sim 8.5$ in aqueous solution. ${ }^{45}$ In this contribution, we examine the

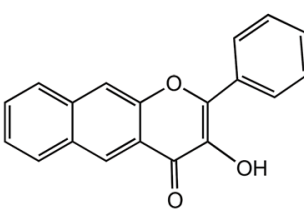

$2 a$

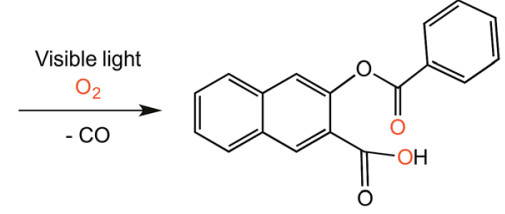

$3 a$
Scheme 1 Visible light-induced CO release reaction of $2 \mathrm{a}$. 

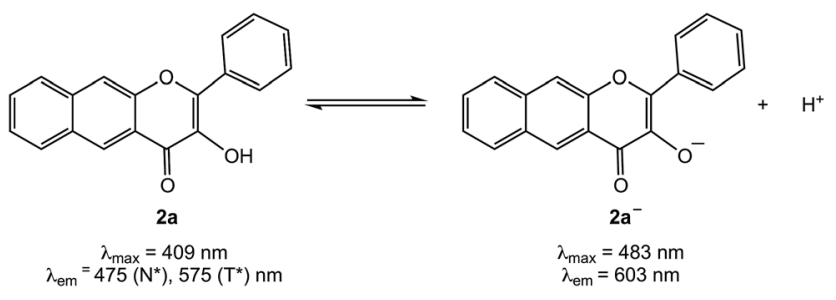

Scheme 2 Acid/base equilibrium of $2 a$.

aqueous solution chemistry of $2 \mathrm{a}$ at $\mathrm{pH}=7.4$ in buffered solutions that include metal ions, surfactants or serum albumin proteins. Our results indicate that the components of the aqueous buffered environment affect the $\mathbf{2 a} / \mathbf{2} \mathbf{a}^{-}$equilibrium (Scheme 2) and modestly influence the quantum yield for CO release. Our studies reveal that $2 \mathbf{a}$ is a reliable CO release motif under a variety of aqueous buffered conditions. Combined with its straight-forward preparation, moderate toxicity, and the nontoxic nature of the $O$-benzoylsalicylate product (3a) remaining following $\mathrm{CO}$ release, $\mathbf{2 a}$ exhibits many features desirable in a photoCORM motif to be further developed for biomedical applications.

\section{Experimental}

\section{Reagents}

Compound 2a was prepared according to the literature procedure. ${ }^{42}$ All reagents were used as received unless otherwise noted. Cetrimonium bromide (CTAB) was purchased from TCI. Sodium dodecylsulfate (SDS) was purchased from Acros Organics. Bovine serum albumin (BSA, heat shock fraction) and human serum albumin (HAS, lyophilized powder, $\geq 97 \%$ ) were purchased from Sigma Aldrich. Warfarin was purchased from Cayman Chemicals Company. Ibuprofen was purchased from Alfa Aesar. Doubledistilled or distilled water was used in all experiments.

\section{Instrumentation}

${ }^{1} \mathrm{H}$ and ${ }^{13} \mathrm{C}$ NMR spectra were collected using a Bruker Avance III HD Ascend-500 spectrometer. UV-vis spectra were recorded at ambient temperature using a Cary 50Bio or a Hewlett-Packard 8453A diode array spectrophotometer. Fluorescence emission spectra were recorded using a Shimadzu RF-530XPC spectrometer using $1.0 \mathrm{~cm}$ quartz cells. The excitation and emission slit widths were set at $3.0 \mathrm{~nm}$. IR spectra were collected using a Shimadzu FTIR-8400 spectrometer. Mass spectral data were collected at the Mass Spectrometry Facility, University of California, Riverside. Elemental analyses were performed by Robertson Microlit Laboratory, Ledgewood, NJ. A Rayonet photoreactor equipped with RPR-419 lamps was used for all photochemical reactions. Quantum yields were determined as previously described using potassium ferrioxalate as a standard to measure photon flux. ${ }^{4-48}$

\section{$\left[(\right.$ bpy $\left.) \mathrm{Zn}\left(2 \mathrm{a}^{-}\right)\right] \mathrm{ClO}_{4}(4)$}

$\mathrm{Zn}\left(\mathrm{ClO}_{4}\right)_{2} \cdot 6 \mathrm{H}_{2} \mathrm{O}(50 \mathrm{mg}, 0.13 \mathrm{mmol})$ dissolved in $1 \mathrm{ml}$ of methanol was added to 2,2'-bipyridine (21 $\mathrm{mg}, 0.13 \mathrm{mmol})$ in
$1 \mathrm{ml}$ of methanol. The resulting mixture was added to a mixture of $2 \mathrm{a}(39 \mathrm{mg}, 0.13 \mathrm{mmol})$ and $\mathrm{Me}_{4} \mathrm{NOH} \cdot 5 \mathrm{H}_{2} \mathrm{O}$ (24 mg, $0.13 \mathrm{mmol})$ in methanol $(2 \mathrm{~mL})$. The reaction mixture was stirred at room temperature for 3 hours. The resulting solution was divided into three parts and solvent was removed under reduced pressure. The remaining residue was dissolved in $\mathrm{CH}_{2} \mathrm{Cl}_{2}$, the solution was filtered through Celite plug, and the solvent was removed under vacuum. The product was recrystallized from $\mathrm{ACN} / \mathrm{Et}_{2} \mathrm{O}$, which resulted in the deposition of X-ray quality crystals $(45 \%)$. IR $\left(\mathrm{KBr}, \mathrm{cm}^{-1}\right)$ $1100\left(\nu_{\mathrm{ClO}_{4}}\right), 623\left(\nu_{\mathrm{ClO}_{4}}\right)$; UV-vis (DMSO, nm) $\left(\varepsilon, \mathrm{M}^{-1} \mathrm{~cm}^{-1}\right) 378$ (3100), 479 (15 100); ESI/APCI MS (positive ion): $\mathrm{m} / \mathrm{z}$ calculated for $\mathrm{C}_{29} \mathrm{H}_{19} \mathrm{~N}_{2} \mathrm{O}_{3} \mathrm{Zn}$ : $507.0722\left[\mathrm{M}-\mathrm{ClO}_{4}\right]^{+}$, found: 507.0699; elemental analysis calc. for $\mathrm{C}_{29} \mathrm{H}_{19} \mathrm{~N}_{2} \mathrm{O}_{7^{-}}$ $\mathrm{ClZn} \cdot 0.5 \mathrm{H}_{2} \mathrm{O}: \mathrm{C}, 56.42 \% ; \mathrm{H}, 3.27 \% ; \mathrm{N}, 4.61 \%$. Found: $\mathrm{C}$ $56.31 ; \mathrm{H}, 2.85 ; \mathrm{N}, 4.60$.

\section{X-ray crystallography}

A translucent light orange plate-like crystal of $\mathbf{4}$ of approximate dimensions $0.140 \mathrm{~mm} \times 0.168 \mathrm{~mm} \times 0.392 \mathrm{~mm}$ was mounted using a viscous oil. Data were collected using a Nonius Kappa CCD diffractometer (Mo K $\alpha, \lambda=0.71073 \AA$ ). A total of 2079 frames were collected and subsequently integrated with the Bruker SAINT software package using a narrow-frame algorithm. The integration of the data using a monoclinic unit cell yielded a total of 51427 reflections to a maximum $\theta$ angle of $30.03^{\circ}$ ( $0.71 \AA$ resolution), of which 7184 were independent (average redundancy 7.159 , completeness $=99.8 \%, R_{\text {int }}=$ $\left.2.75 \%, R_{\text {sig }}=1.73 \%\right)$ and $6280(87.42 \%)$ were greater than $2 \sigma\left(F^{2}\right)$. The final cell constants of $a=8.2518(2) \AA, b=14.8377(4)$ $\AA, c=20.0844(6) \AA, \beta=92.219(2)$, volume $=2457.24(12) \AA^{3}$, are based upon the refinement of the $X Y Z$-centroids of reflections above $20 \sigma(I)$. Data were corrected for absorption effects using the multi-scan method (SADABS). The calculated minimum and maximum transmission coefficients (based on crystal size) are 0.6600 and 0.8540 , respectively.

The structure of $\mathbf{4}$ was solved and refined using the Bruker SHELXTL Software Package, using the space group $P 2 \overline{1} n$ with $Z$ $=4$ for the formula unit $\mathrm{C}_{29} \mathrm{H}_{19} \mathrm{ClN}_{2} \mathrm{O}_{7} \mathrm{Zn}$. The final anisotropic full-matrix least-squares refinement on $F^{2}$ with 370 variables converged at $R_{1}=3.18 \%$, for the observed data and $\mathrm{w} R_{2}=$ $8.97 \%$. The goodness-of-fit was 1.062 . The largest peak in the final difference electron density was $1.263 \mathrm{e}^{-} \AA^{-3}$ with an RMS deviation of $0.066 \mathrm{e}^{-} \AA^{-3}$. On the basis of the final model, the calculated density was $1.644 \mathrm{~g} \mathrm{~cm}^{-3}$ and $\mathrm{F}(000), 1240 \mathrm{e}^{-}$. The structure was deposited in the Cambridge Crystallographic Database (CCDC 1523782).

\section{Buffer preparation}

TRIS $(0.05 \mathrm{M})$ at $\mathrm{pH}=7.4$ was prepared using a mixture of TRIS$\mathrm{HCl}$ and TRIS-base. Sodium chloride $(0.1 \mathrm{M})$ was added to maintain ionic strength. Phosphate buffered saline (PBS) was prepared containing $140 \mathrm{mM} \mathrm{NaCl}, 3 \mathrm{mM} \mathrm{KCl}$, and $10 \mathrm{mM}$ phosphate and was adjusted to $\mathrm{pH}=7.4$ using aqueous $\mathrm{HCl}$. 


\section{Solution studies of $2 \mathrm{a}$ in the presence of CTAB and SDS}

Experiments were performed in PBS : DMSO (96.7 : 3.3\% v:v, $\mathrm{pH}=7.4)$. The absorption and emission properties of $2 \mathbf{a}$ were evaluated in the presence of varying amounts of CTAB or SDS.

\section{Solution studies of $2 \mathrm{a}$ in the presence of bovine or human serum albumin}

Emission spectra of solutions of $2 \mathrm{a}\left(1.4 \times 10^{-6} \mathrm{M}\right)$ in TRIS : DMSO (96:4\% v:v, pH =7.4) were collected from 410 to $800 \mathrm{~nm}$ in the presence of varying amounts of bovine or human serum albumin $(1: 0$ to $1: 40)$. The excitation wavelength was $408 \mathrm{~nm}$, which corresponds to the absorption maximum of $2 \mathbf{a}$.

\section{Serum albumin binding studies}

Binding studies of $2 \mathbf{a}$ to bovine or human serum albumin were performed using tryptophan fluorescence quenching experiments in TRIS : DMSO (96:4\% v:v, $\mathrm{pH}=7.4$ ). The excitation wavelengths used for BSA and HSA were 282 and $285 \mathrm{~nm}$, respectively. Emission spectra were recorded from 300 to $600 \mathrm{~nm}$. The maximum emission intensities at $340 \mathrm{~nm}$ were used to calculate binding constants and to determine the number of binding sites.

\section{Molecular docking}

Studies were performed using AutoDock Vina 1.1.2 software. $^{49}$ The crystal structure of BSA was downloaded from the RSCB Protein Data Bank (PDB entry code 3V03). The X-ray crystallographically determined structure of $\mathbf{2} \mathbf{a}^{\mathbf{4 2}}$ was converted to pdbqt format with MGLTools for use as an input file for AutoDock Vina. A structure of the $O$-benzoylsalicylic acid CO release product 3a was energy minimized using Chem 3D (MM2 force field) and saved in pdbqt format using MGLTools for input into AutoDock Vina. A semi-flexible docking procedure was performed wherein BSA was kept rigid and stationary and was assigned with polar hydrogen atoms. Compound 2a with two rotatable bonds and $\mathbf{3 a}$ with five rotatable bonds were allowed to be flexible as they were docked into the protein. A grid box with dimensions $60 \times 68 \times 68$ points with the spacing of $1.0 \AA$ was used to accommodate the ligands to move freely during each docking run. The lowest energy docked conformations identified for $\mathbf{2 a}$ and $\mathbf{3 a}$ with BSA were visualized using Pymol.

\section{Independent synthesis of 3-(benzoyloxy)-2-naphthoic acid (3a)}

3-Hydroxy-2-naphthoic acid, (0.50 g, $2.7 \mathrm{mmol})$ in $3 \mathrm{ml}$ dry diethyl ether was mixed with pyridine $(0.58 \mathrm{ml}, 7.2 \mathrm{mmol})$. The resulting mixture was cooled in an ice bath and a solution of benzoyl chloride $(0.31 \mathrm{ml}, 2.7 \mathrm{mmol})$ in diethyl ether $(2 \mathrm{~mL})$ was added. The reaction mixture was warmed to room temperature and then stirred for 1 hour. $\mathrm{H}_{2} \mathrm{O}(10 \mathrm{ml})$ was then added. The solution was acidified with $2 \mathrm{M} \mathrm{HCl}$ until $\mathrm{pH} \sim 4$ was obtained. The mixed aqueous/organic mixture was then extracted using chloroform $(3 \times 15 \mathrm{ml})$. The organic fractions were combined, dried over $\mathrm{Na}_{2} \mathrm{SO}_{4}$, the solution was filtered, and the solvent was removed from the filtrate under reduced pressure. The product was purified by column chromatography using hexanes : ethyl acetate (1:1) as the eluent. 3-(Benzoyloxy)-2-naphthoic acid (3a) was obtained as colorless needles $(0.20 \mathrm{~g}, 25 \%)$ following removal of solvent. The ${ }^{1} \mathrm{H}$ NMR features of the product in $\mathrm{CD}_{3} \mathrm{CN}$ matched with those previously reported. ${ }^{42}{ }^{1} \mathrm{H}$ NMR (500 $\left.\mathrm{MHz}, \mathrm{CD}_{3} \mathrm{OD}\right) \delta \mathrm{ppm} 8.66(\mathrm{~s}, 1 \mathrm{H}), 8.23$ (d, $\left.J=9 \mathrm{~Hz}, 2 \mathrm{H}\right), 8.05$ (d, $J$ $=9.5 \mathrm{~Hz}, 1 \mathrm{H}), 7.93(\mathrm{~d}, J=9 \mathrm{~Hz}, 1 \mathrm{H}), 7.73(\mathrm{~s}, 1 \mathrm{H}), 7.69(\mathrm{t}, J=$ $7.5 \mathrm{~Hz}, 1 \mathrm{H}), 7.65(\mathrm{t}, J=7.5 \mathrm{~Hz}, 1 \mathrm{H}), 7.56(\mathrm{~m}, 3 \mathrm{H}) ;{ }^{13} \mathrm{C}\left\{{ }^{1} \mathrm{H}\right\} \mathrm{NMR}$ (125 MHz, $\left.\mathrm{CD}_{3} \mathrm{OD}\right) \delta 169.4,169.0,149.9,138.5,136.2,136.1$, $133.6,132.7,132.6,131.5,131.4,131.1,129.8,129.3,125.9$, $123.6 \mathrm{ppm}$ (16 signals expected and observed); IR (KBr, $\mathrm{cm}^{-1}$ ) $1743\left(\nu_{\mathrm{C}=\mathrm{o}}\right)$; ESI/APCI MS (negative ion): $\mathrm{m} / \mathrm{z}$ calculated for $\mathrm{C}_{18} \mathrm{H}_{12} \mathrm{O}_{4}$ : 291.0657, found: 291.0674 . m.p. $173-175^{\circ} \mathrm{C}$.

\section{Results}

\section{Properties of 2a in $1: 1$ DMSO : aqueous buffer at $\mathbf{p H}=7.4$}

When dissolved in 1:1 DMSO : Tris buffer at $\mathrm{pH}$ 7.4, compound 2a exhibits features consistent with the presence of the neutral flavonol (Fig. 3). Specifically, an absorption band with a maximum at approximately $\sim 409 \mathrm{~nm}$ is similar to that observed for the compound in $\mathrm{CH}_{3} \mathrm{CN}$ and $1: 1$ DMSO : $\mathrm{H}_{2} \mathrm{O} \cdot{ }^{42}$ When 2a is dissolved in 1:1 DMSO : PBS buffer at $\mathrm{pH} 7.4$ (Fig. 3), an absorption feature at $\sim 480 \mathrm{~nm}$ is also present. This red-shifted band is consistent with the presence of the flavonolato anion $\left(2 \mathbf{a}^{-}\right)$based on comparison to spectroscopic features of $\mathrm{Zn}$ (II) complexes of $2 \mathbf{a}^{-} .^{44}$ The same $480 \mathrm{~nm}$ band is present when 2a is dissolved in $1: 1$ DMSO : $\mathrm{H}_{2} \mathrm{O}$ to which two equivalents of sodium hydroxide has been added (Fig. S1(a) $\dagger$ ).

Fluorescence spectra $\left(\lambda_{\mathrm{ex}}=410\right.$ and $\left.480 \mathrm{~nm}\right)$ of $1: 1$ DMSO : buffer solutions $(\mathrm{pH}=7.4)$ of $2 \mathrm{a}$ provide additional evidence for the presence of neutral and anionic forms of $\mathbf{2 a}$ under various conditions. When excited at $410 \mathrm{~nm}$, solutions of 2a in $1: 1$ DMSO : $\mathrm{H}_{2} \mathrm{O}$, DMSO : TRIS and $1: 1$ DMSO : PBS at $\mathrm{pH}=7.4$ exhibit two emission bands at $\sim 475$ and $\sim 580 \mathrm{~nm}$ (Fig. 4), respectively. These emissions are from the normal $\left(\mathrm{N}^{*}\right)$ and tautomeric $\left(\mathrm{T}^{*}\right)$ excited state forms of $2 \mathrm{a}^{50}$ The $\mathrm{T}^{*}$ form is

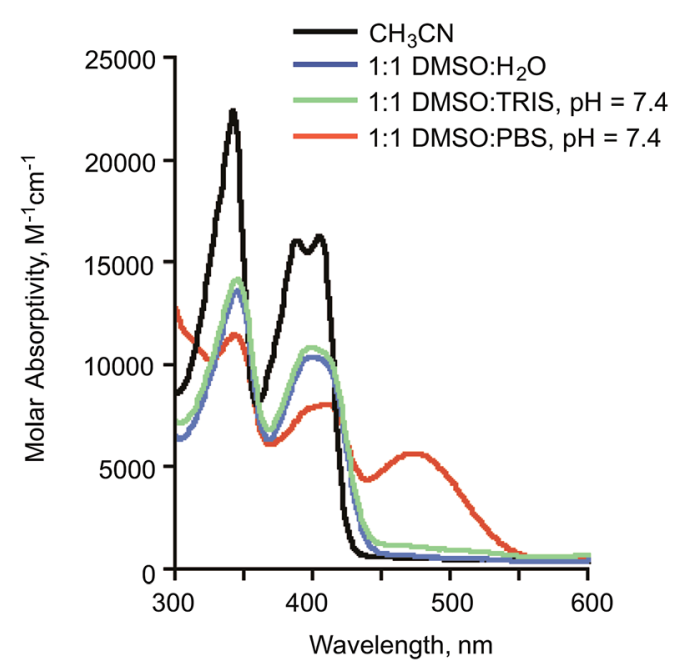

Fig. 3 Absorbance spectra of $2 a(0.10 \mathrm{mM})$ in various solution environments. The $\sim 480 \mathrm{~nm}$ absorption feature present in 1:1 DMSO : PBS at $\mathrm{pH} 7.4$ is associated with the presence of $2 \mathrm{a}^{-}$. 


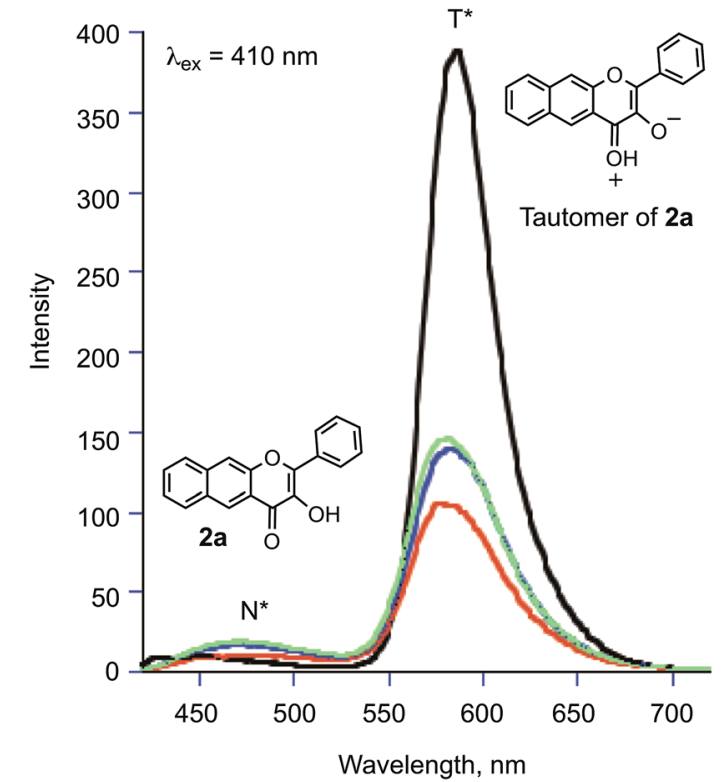

Fig. 4 Emission spectra $\left(\lambda_{\mathrm{ex}}=410 \mathrm{~nm}\right)$ of solutions of $2 \mathrm{a}(0.10 \mathrm{mM})$.

the result of excited state proton transfer (ESPT) within the flavonol and formation of the pyrillium ion (Fig. 4). The intensity of the $\mathrm{T}^{*}$ emission is lower than that exhibited by $\mathbf{2 a}$ in organic solvent $\left(\mathrm{CH}_{3} \mathrm{CN}\right)$ due to the availability of additional non-radiative pathways in the hydrogen bonding aqueous solutions which results in quenching of the excited state. ${ }^{51}$ The emission maximum in aqueous environments is also slightly blue-shifted relative to the spectrum of $2 \mathbf{a}$ in $\mathrm{CH}_{3} \mathrm{CN}$. Excitation of the same solutions at $480 \mathrm{~nm}$ produced an emission at $\sim 603 \mathrm{~nm}$ in the solution of 2a in $1: 1$ DMSO : PBS buffer. A $1: 1$ DMSO : $\mathrm{H}_{2} \mathrm{O}$ solution containing two equivalents of sodium hydroxide gives a similar emission feature (Fig. S1(c) †) providing evidence that this emission is associated with $2 \mathbf{a}^{-}$.

\section{Zinc complex}

To gain insight into the properties of $\mathbf{2 a}^{-}$in aqueous buffer in the presence of a divalent metal ion, we have prepared and characterized $\left[(\mathrm{bpy}) \mathrm{Zn}\left(2 \mathrm{a}^{-}\right)\right] \mathrm{ClO}_{4}(\mathbf{4})$ and performed spectroscopic studies of this complex. In the solid state, 4 exhibits a binuclear structure (Fig. 6(a)) with the deprotonated oxygen atom of each flavonolato ligand bridging between two zinc centers. This coordination motif is similar to that found in $[($ bpy $) \mathrm{Zn}(3-\mathrm{Hfl})] \mathrm{ClO}_{4}$ (3-Hfl = 3-hydroxyflavonolato anion). ${ }^{52}$ ESI APCI mass spectral studies of 4 in wet $\mathrm{CH}_{3} \mathrm{CN}$ (Fig. S2 $\dagger$ ) indicate that the mononuclear $\left[(\mathrm{bpy}) \mathrm{Zn}\left(2 \mathrm{a}^{-}\right)\right]^{+}$ion is present indicating breakup of the dimer in solution. Additionally, species resulting from ligand exchange (e.g., $\left[(\mathrm{bpy})_{2} \mathrm{Zn}\left(\mathrm{ClO}_{4}\right)\right]^{+}$and $\left.\left[(\mathrm{bpy})_{2} \mathrm{Zn}\right]^{2+}\right)$ and ligand loss $\left(\right.$ e.g.,$[\mathrm{bpyH}]^{+}$and $\left.[\mathbf{2 a}] \mathrm{H}^{+}\right)$are evident in the mass spectrum. The UV-vis spectrum of 4 in dry $\mathrm{CH}_{3} \mathrm{CN}$, and
$1: 1$ DMSO : TRIS and $1: 1$ DMSO $:$ PBS at $\mathrm{pH}=7.4$, are shown in Fig. 6(b). The DMSO : buffer solutions show features consistent with the presence of neutral and anionic forms of 2 a. The emission spectra of $4\left(\lambda_{\mathrm{ex}}=410 \mathrm{~nm}\right.$; Fig. 6(c)) in $1: 1$ DMSO : TRIS and $1: 1$ DMSO : PBS at $\mathrm{pH}=7.4$ confirm the presence of the neutral flavonol. Excitation at $480 \mathrm{~nm}$ (Fig. 6(d)) produces an emission feature at $\sim 554 \mathrm{~nm}$ in $1: 1$ DMSO : TRIS and $\sim 603 \mathrm{~nm}$ in $1: 1 \mathrm{DMSO}$ : PBS. The differences in these spectra are indicative of the presence of zinc-coordinated $2 \mathbf{a}^{-}$ and free $2 \mathrm{a}^{-}$anion, respectively. The attribution of the emission at $\sim 563 \mathrm{~nm}$ to $\mathrm{Zn}$ (II) coordinated $2 \mathrm{a}^{-}$is made on the basis of prior studies. ${ }^{44}$ These results indicate that the zinc ion stays associated with the $2 \mathrm{a}^{-}$anion in $1: 1$ DMSO $:$ TRIS at $\mathrm{pH}=7.4$, but is displaced from the zinc center in $1: 1$ DMSO : PBS at the same $\mathrm{pH}$.

\section{Effects of surfactants}

The flavonol 2a exhibits low solubility in PBS buffer in the presence of low amounts of DMSO ( $3 \%)$. This is evident in the lack of a flavonol emission feature of a solution of this composition and observed precipitation. However, in $1: 1$ DMSO : buffer, 2a is soluble. In order to minimize the amount of DMSO present and gain insight into how the solubility of 2a may be impacted by interactions with other biomolecules or charged species, we have investigated the solution spectroscopic properties of $\mathbf{2 a}$ in the presence of surfactants. In the presence of the cationic surfactant CTAB (centrimonium bromide), compound 2a exhibits absorption and emission spectra consistent with the presence of a mixture of $\mathbf{2 a}$ and $2 \mathbf{a}^{-}$ (Fig. 7). The emission features associated with these species increase in intensity with increasing CTAB concentration (Fig. 7(b) and (c)), which is similar to studies involving 3hydroxyflavone. ${ }^{53}$

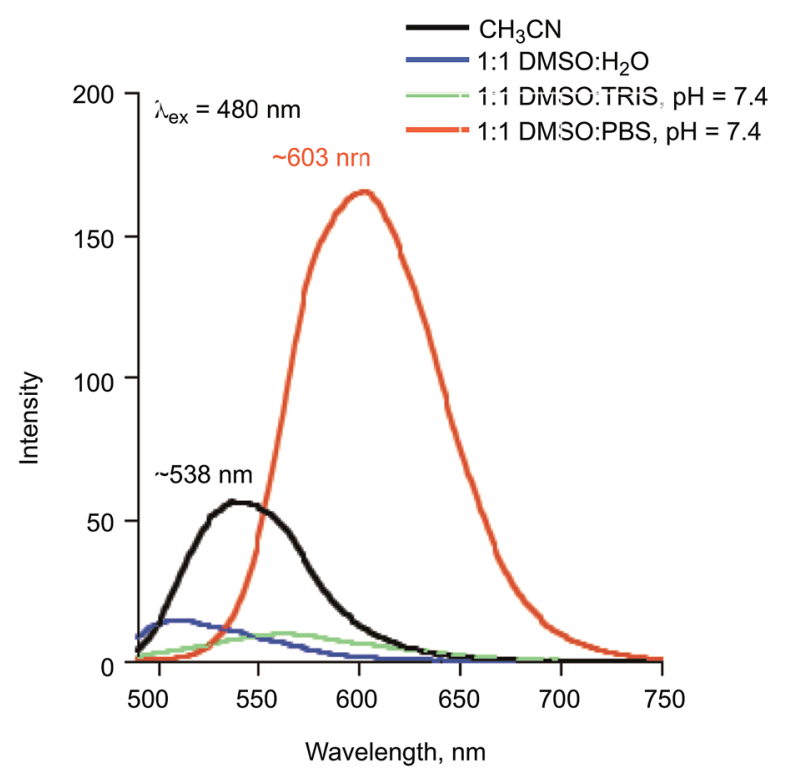

Fig. 5 Emission spectra $\left(\lambda_{\text {ex }}=480 \mathrm{~nm}\right)$ of solutions of $2 a(0.10 \mathrm{mM})$. The emission feature for $2 \mathrm{a}$ at $\sim 538 \mathrm{~nm}$ in $\mathrm{CH}_{3} \mathrm{CN}$ is attributed to the neutral flavonol. 

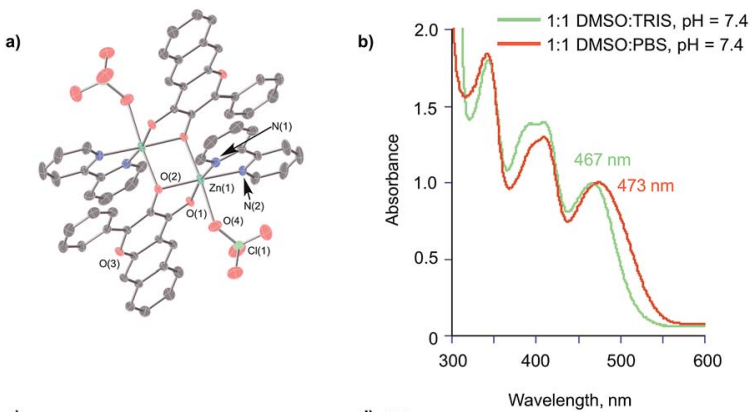

c)

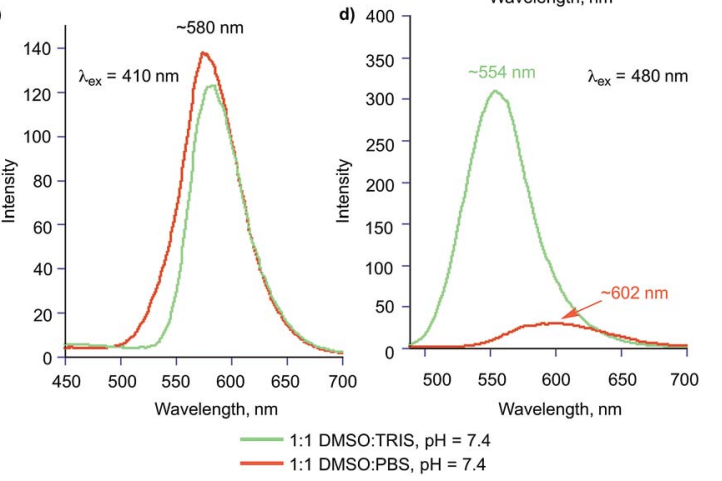

Fig. 6 (a) Thermal ellipsoid representation (50\% ellipsoids) of the binuclear structure of 4 . (b) Absorption spectra of $4(0.10 \mathrm{mM})$ in $1: 1$ DMSO : TRIS and $1: 1$ DMSO : PBS at $\mathrm{pH}=7.4$. (c) Emission spectra produced with $\lambda_{\mathrm{ex}}=410 \mathrm{~nm}$. (d) Emission spectra produced with $\lambda_{\mathrm{ex}}=$ $480 \mathrm{~nm}$.

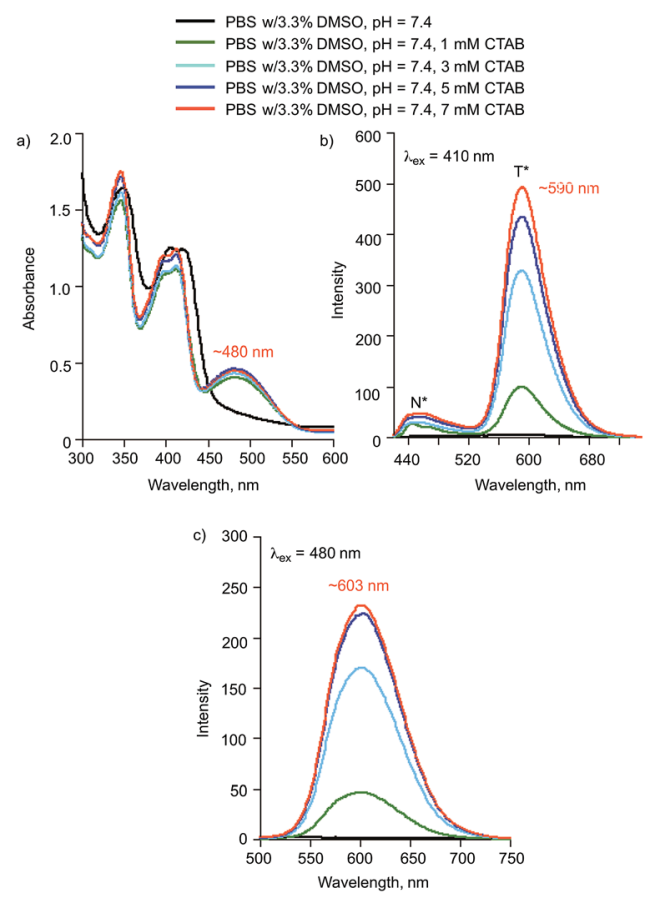

Fig. 7 (a) Absorption spectra of $2 a(0.10 \mathrm{mM})$ in the presence of various concentrations of CTAB. (b) Emission spectra produced with $\lambda_{\mathrm{ex}}=410 \mathrm{~nm}$. (c) Emission spectra produced with $\lambda_{\mathrm{ex}}=480 \mathrm{~nm}$.

In the presence of sodium dodecyl sulphate (SDS), the absorption and emission features of $2 \mathbf{a}$ are consistent with the presence of only the neutral form of the flavonol (Fig. 8). This is

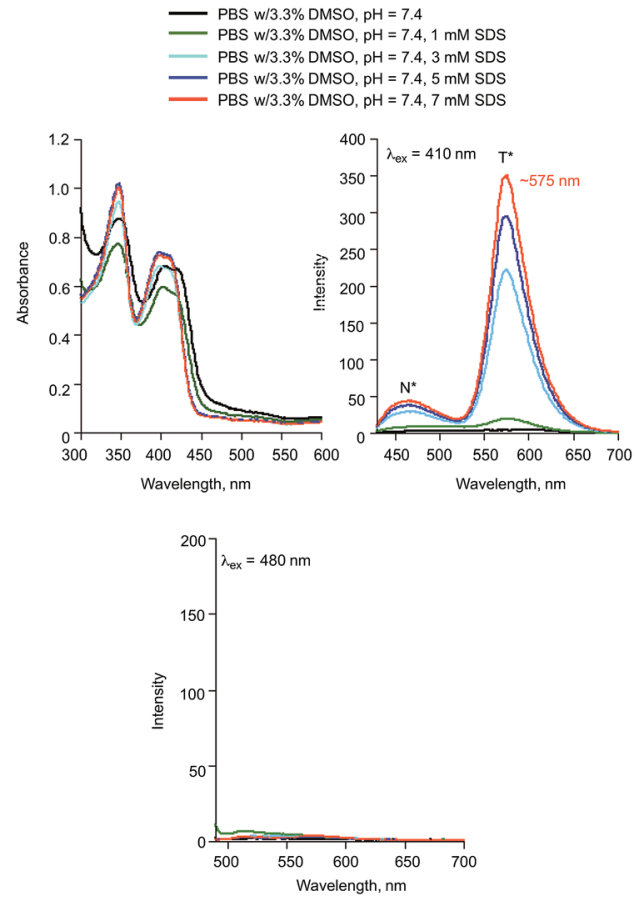

Fig. 8 (a) Absorption spectra of $2 a(0.10 \mathrm{mM})$ in the presence of various concentrations of SDS. (b) Emission spectra produced with $\lambda_{\text {ex }}$ $=410 \mathrm{~nm}$. (c) Emission spectra produced with $\lambda_{\mathrm{ex}}=480 \mathrm{~nm}$.

particularly evident in the lack of an emission feature upon excitation at $480 \mathrm{~nm}$.

\section{Serum albumins}

Several studies of the binding properties of flavonols to serum albumin proteins using fluorescence spectroscopy have been previously reported ${ }^{54-62}$ In the case of $2 \mathbf{a}$, we selectively examined the fluorescence properties of both the flavonol and the tryptophan residues of the protein to probe the $2 \mathbf{a}$ /albumin interaction. Addition of aliquots of BSA to the flavonol in TRIS : DMSO ( $96: 4 \% \mathrm{v}: \mathrm{v}, \mathrm{pH}=7.4$ ) results in a saturatable increase in the intensity of the flavonol $\mathrm{T}^{*}$ emission band (Fig. 9). A bathochromic shift $(\sim 30 \mathrm{~nm})$ of this emission is observed. We note that a similar red shift of the tautomer fluorescence band was identified for 3-hydroxyflavone (3-HflH) upon binding to BSA. ${ }^{54}$ Notably, the emission maximum observed for $2 \mathbf{a}$ in the presence of BSA matches that found in a polar aprotic organic solvent (e.g., $\mathrm{CH}_{3} \mathrm{CN}$ (Fig. 4)) wherein the ESIPT process is efficient. This suggests a hydrophobic binding site for the flavonol within the protein environment. As shown in Fig. 10, addition of 2a to BSA in TRIS : DMSO (96 : 4\% v:v, pH $=7.4)$ results in a decrease of the $340 \mathrm{~nm}$ intrinsic emission $\left(\lambda_{\mathrm{ex}}\right.$ $=282 \mathrm{~nm}$ ) associated with the tryptophan residues of the protein. This quenching suggests that $\mathbf{2 a}$ binds in close proximity to the tryptophan residues (positions 134 and 213). Notably, similar quenching is seen upon titration of human serum albumin (HSA), which contains a single tryptophan residue at position 214 in subdomain IIA of the protein (Fig. S3 $\dagger$ ). For each protein, the Stern-Volmer equation (eqn (1)) 


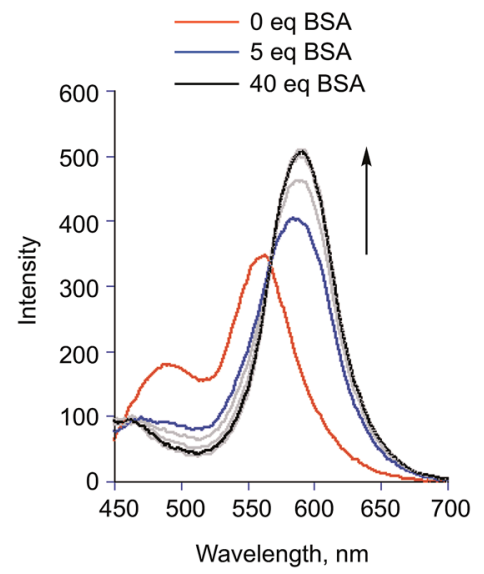

Fig. 9 Emission features of $2 \mathrm{a}(1.4 \mu \mathrm{M})$ upon addition of increasing amounts of BSA in TRIS : DMSO (96:4\% v:v, $\mathrm{pH}=7.4) . T=293 \mathrm{~K}, \lambda_{\mathrm{ex}}=$ $410 \mathrm{~nm}$.
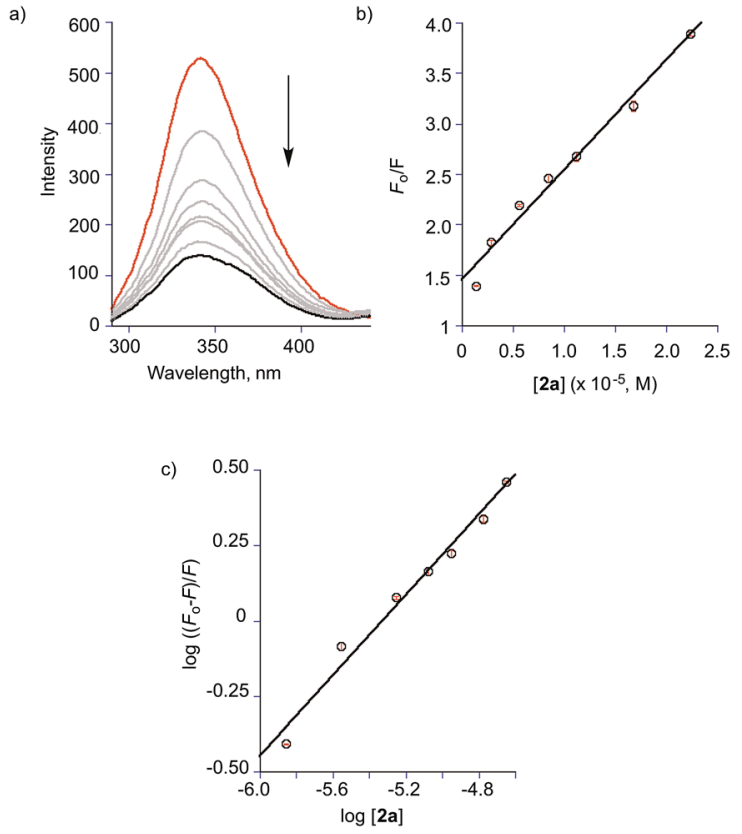

Fig. 10 (a) Fluorescence emission spectra of BSA $(1.4 \mu \mathrm{M})$ in the presence of various concentrations of $2 a$ in TRIS/ $\mathrm{NaCl}$ : DMSO (96: $4 \% \mathrm{v}: \mathrm{v}, \mathrm{pH}=7.4$ ); $T=298 \mathrm{~K}, \lambda_{\mathrm{ex}}=282 \mathrm{~nm}$. [2a] $=0,1.4,2.8,5.6$, $8.4,11.2,16.8$, and $22.4 \mu \mathrm{M}$. (b) Stern-Volmer plot of data for titration of BSA with 2a. (c) Modified Stern-Volmer plot of data for titration of BSA with $2 a$.

was used to classify the type of fluorescence quenching induced by $\mathbf{2 a}$ as static or dynamic. ${ }^{54}$

$$
\frac{F_{0}}{F}=1+k_{\mathrm{q}} \tau_{0}[Q]=1+K_{\mathrm{sv}}[Q]
$$

In this equation, $F_{0}$ and $F$ are the fluorescence intensities in the absence and presence of the quencher (2a), respectively; $k_{\mathrm{q}}$ is the bimolecular quenching constant, $\tau_{0}$ is the lifetime of the fluorophore in the absence of quencher $\left(10^{-8} \mathrm{~s}\right)$, [Q] is the concentration of the quencher and $K_{\mathrm{sv}}$ is the Stern-Volmer bimolecular quenching constant. ${ }^{54}$ The Stern-Volmer plot for the titration of BSA with $2 \mathrm{a}$ is shown in Fig. 10 (b). As $k_{\mathrm{q}}(1.1 \times$ $10^{13} \mathrm{M}^{-1} \mathrm{~s}^{-1}$ ) is much larger than $2 \times 10^{10} \mathrm{M}^{-1} \mathrm{~s}^{-1}$ (the maximum diffusion collision quenching rate constant of various quenchers with the biopolymer), it is likely that the quenching in this case is static in nature. ${ }^{54}$ The binding constant $K_{\mathrm{a}}$ and number of binding sites $n$ were calculated from the modified Stern-Volmer plot (Fig. 10(c)) for the titrations of BSA with 2a according to eqn (2):

$$
\log \left(\frac{F_{0}-F}{F}\right)=\log K_{\mathrm{a}}+n \log [Q]
$$

where $[Q]$ is [2a]. A plot of $\log \left(\left(F_{0}-F\right) / F_{0}\right)$ versus $\log [Q]$ yields $\log K_{\mathrm{a}}$ as the intercept and $n$ as the slope (Fig. 10(c)). The binding constant $K_{\mathrm{a}}$ and binding sites $n$ for 2a with BSA and HSA are listed in Table 1 . Notably, only one equivalent of $2 \mathbf{a}$ binds to BSA and HSA versus two equivalents of the structurally similar but smaller 3-hydroxyflavone (3-HflH) ${ }^{54,55}$ The binding constant for $2 \mathrm{a}$ is $\sim 45$-fold lower than that of $3-\mathrm{HflH}$ and is also significantly lower than that of hydroxyl-substituted $3-\mathrm{HflH}$ derivatives that are naturally occurring compounds (e.g., quercetin and morin; Table 1).

Most drug molecules bind to BSA in subdomains IIA and IIIA. Site I (subdomain IIA) is where the blood thinner drug warfarin binds whereas Site II (subdomain IIIA) is the location of ibuprofen binding. ${ }^{63}$ To gain insight into the binding site of 2a in BSA, displacement studies were performed with warfarin and ibuprofen. Pre-equilibration of a BSA : warfarin $(1: 1)$ mixture for $1 \mathrm{~h}$ followed by titration with $2 \mathrm{a}$ resulted in the loss of tryptophan fluorescence intensity. The binding constant for

Table 1 Binding constants of $2 a$ and $3 a$ with serum albumin proteins at $22{ }^{\circ} \mathrm{C}$ with comparisons to other flavonols and salicylic acid derivatives

\begin{tabular}{llll}
\hline Compound & $\begin{array}{l}\text { Binding constant } \\
\left(K_{\mathrm{a}}, \mathrm{M}^{-1}\right)\end{array}$ & $n$ & Ref. \\
\hline 2a-BSA & $3.2 \times 10^{3}$ & 0.66 & This work \\
2a-BSA $\left(\mathrm{Zn}^{2+}\right)$ & $1.9 \times 10^{2}$ & 0.48 & This work \\
{$\left[(\mathrm{bpy}) \mathrm{Zn}\left(\mathbf{2 a}^{-}\right)\right] \mathrm{ClO}_{4}$} & $1.0 \times 10^{2}$ & 0.39 & This work \\
2a-BSA $\left(\mathrm{Ca}^{2+}\right)$ & $3.2 \times 10^{3}$ & 0.71 & This work \\
2a-BSA (Mg $\left.\mathrm{Mg}^{2+}\right)$ & $2.5 \times 10^{3}$ & 0.69 & This work \\
2a-BSA (warfarin) & $2.8 \times 10^{2}$ & 0.46 & This work \\
2a-BSA (ibuprofen) & $2.5 \times 10^{3}$ & 0.67 & This work \\
2a-HSA & $3.0 \times 10^{3}$ & 0.7 & This work \\
2a-HSA (warfarin) & $2.5 \times 10^{3}$ & 0.66 & This work \\
2a-HSA (ibuprofen) & $3.0 \times 10^{3}$ & 0.67 & This work \\
3-HFlH-BSA & $1.1-1.3 \times 10^{5}$ & 2 & 54 \\
3-HflH-HSA & $7.2 \times 10^{5} ; 2.5 \times 10^{5}$ & 2 & 55 \\
Quercetin-BSA & $3.65 \times 10^{7}$ & 1.29 & 56 \\
Quercetin-BSA & $1.00 \times 10^{5}$ & 0.84 & 57 \\
Quercetin-BSA & $4.85 \times 10^{5}$ & 1.19 & 58 \\
Quercetin-HSA & $2.30 \times 10^{4}$ & 1.10 & 58 \\
Morin-HSA & $1.13 \times 10^{5}$ & 1.06 & 59 \\
3a-BSA & $8.5 \times 10^{7}$ & 1.7 & This work \\
3a-BSA (warfarin) & $6.7 \times 10^{3}$ & 0.9 & This work \\
3a-BSA (ibuprofen) & $2.5 \times 10^{5}$ & 1.2 & This work \\
BSA-aspirin & $5.0 \times 10^{3}$ & & 64
\end{tabular}


2a determined from this data $\left(2.8 \times 10^{2} \mathrm{M}^{-1}\right.$; Fig. S4(a) $\left.\dagger\right)$ is lower than that observed in the absence of warfarin, suggesting competition for the binding site. A similar experiment involving ibuprofen (Fig. S4(b) †) produced almost no change in the binding constant for $2 \mathrm{a}$, indicating that no binding of this compound occurs in Site II.

To further probe the binding site of 2a with BSA we performed in silico docking studies using AutoDock Vina. ${ }^{49}$ Two different high affinity binding conformations (Fig. 11) were identified near Site I in subdomain IIA. One of these conformations includes hydrogen-bonding interactions involving the ketone moiety of 2a (Fig. 11(a)). Because these interactions would preclude the formation of the tautomeric excited state form of $\mathbf{2 a}$, which is observed by fluorescence, the other conformation (Fig. 11(b)) is more likely. In this binding mode, the hydroxyl oxygen atom, which would be deprotonated in the tautomeric form, is stabilized by the presence of multiple hydrogen bonding interactions.

Human serum albumin (HSA) contains only a single tryptophan residue near Site I. The binding properties for 2a to HSA are similar to that observed for BSA, with a single molecule binding with a binding constant of $3.0 \times 10^{3} \mathrm{M}^{-1}$ (Fig. S3(ac) $\dagger$ ). Warfarin and ibuprofen experiments with 2 a produced a less pronounced effect relative to those observed for BSA (Fig. S5(a) and (b) $\dagger$ ), with a modest affect on binding of 2 a only being observed in the presence of warfarin. Overall, these combined results strongly suggest that serum albumin proteins bind $2 \mathbf{a}$ at Site I.

a)

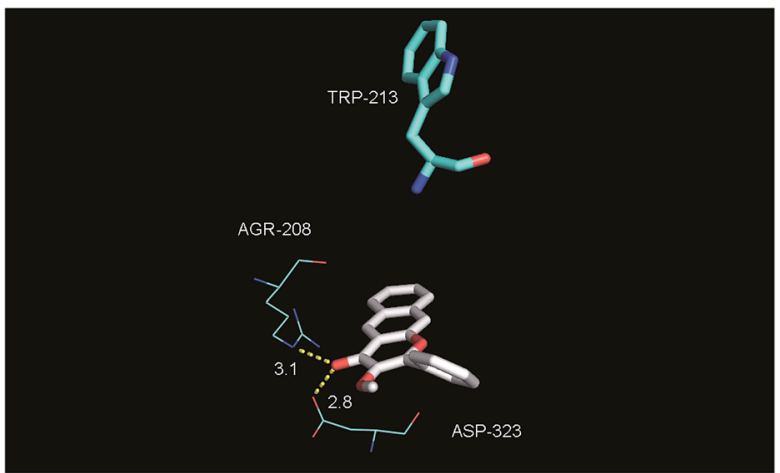

b)

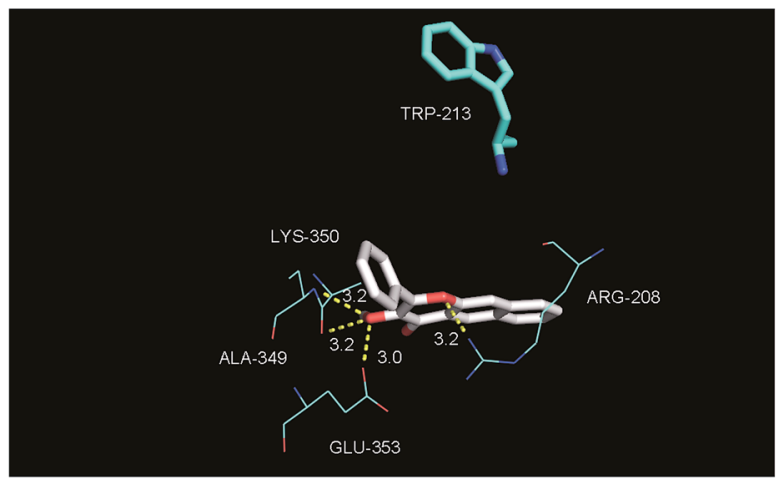

Fig. 11 Views of the binding of $2 a$ to BSA near Site I in subdomain IIA. Both conformations have similar energies.
The binding properties of the $O$-benzoylsalicylate $\mathrm{CO}$ release product 3a with BSA were also briefly examined. As shown in Fig. 12(a), this molecule also quenches the intrinsic fluorescence of the protein. A modified Stern-Volmer analysis (Fig. 12(c)) revealed that the binding affinity of 3a to BSA is significantly higher $\left(K_{\mathrm{a}} \sim 10^{7} \mathrm{M}^{-1}\right)$ than that of $2 \mathrm{a}$. Two molecules of $3 \mathbf{a}$ bind to BSA. Competitive binding studies performed using warfarin and ibuprofen (Fig. S6†) show significant changes in the binding constant for $\mathbf{3 a}$ in the presence of both of these site markers. Docking of 3a with BSA resulted in the identification of two binding sites, with the first being Site I in subdomain IIA and the second being a hydrophobic pocket in subdomain IB. As shown in Fig. 13, binding for $O$-benzoylsalicylate derivative in Site I, which is likely the higher affinity binding site, involves hydrogen-bonding interactions with two nearby residues (ARG-208, Glu-353). In subdomain IB, which is a secondary binding site for several drugs including AZT, ${ }^{65,66}$ the interactions appear to be exclusively hydrophobic. Overall, the distinctly different serum albumin binding properties of $2 \mathbf{a}$ and 3a place these compounds near the bookends of the range of many known drug molecules that exhibit binding constants of $10^{4}-10^{7} \mathrm{M}^{-1}$ at Site I in HSA. ${ }^{65}$

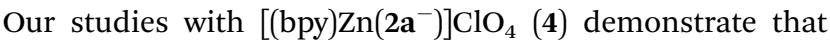
$\mathrm{Zn}^{2+}$ will form coordination complexes with the anion $2 \mathbf{a}^{-}$. To examine the effect of metal ions on the protein binding properties of 2a in aqueous buffer, titrations of solutions of BSA (1.4 $\mu \mathrm{M})$ containing $150 \mu \mathrm{M} \mathrm{M}{ }^{n+}\left(\mathrm{M}^{n+}=\mathrm{Mg}^{2+}, \mathrm{Ca}^{2+}\right.$, and $\left.\mathrm{Zn}^{2+}\right)$ with 2a were performed. As shown in Table 1, the presence of $\mathrm{Zn}^{2+}$
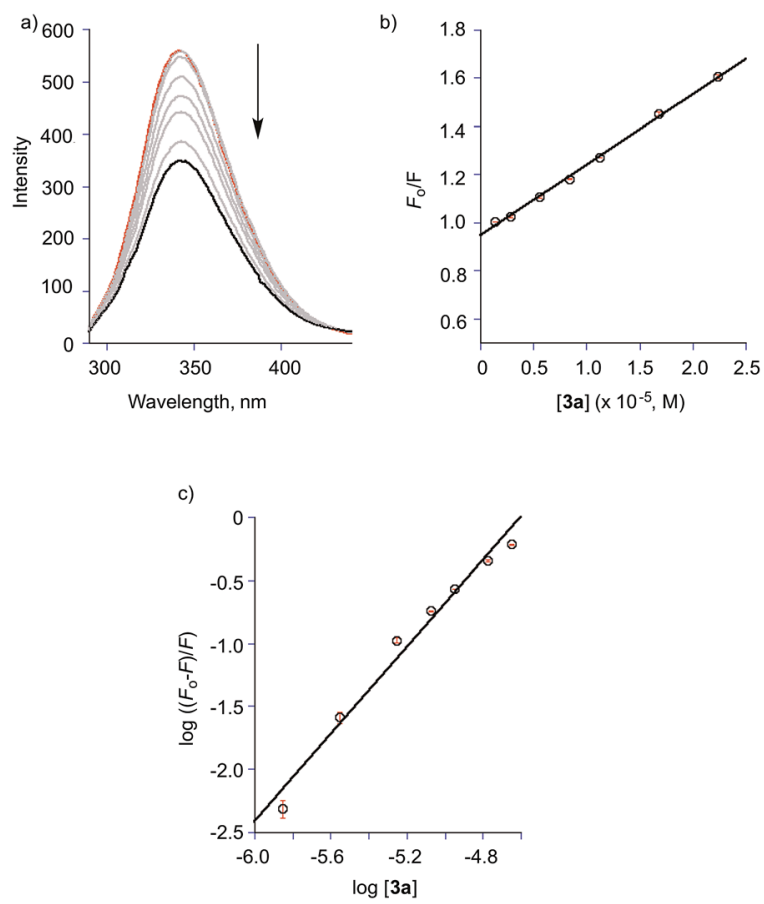

Fig. 12 (a) Fluorescence emission of spectrum of BSA $(1.4 \mu \mathrm{M})$ in presence of various concentrations of $3 \mathrm{a}$ in TRIS buffer at $\mathrm{pH}=7.4 ; T=$ $298 \mathrm{~K}, \lambda_{\mathrm{ex}}=282 \mathrm{~nm}$. [3a] $=0,1.4,2.8,5.6,8.4,11.2,16.8$, and $22.4 \mu \mathrm{M}$. (b) Stern-Volmer plot of data for titration of BSA with 3a. (c) Modified Stern-Volmer plot of data for titration of BSA with 3a. 


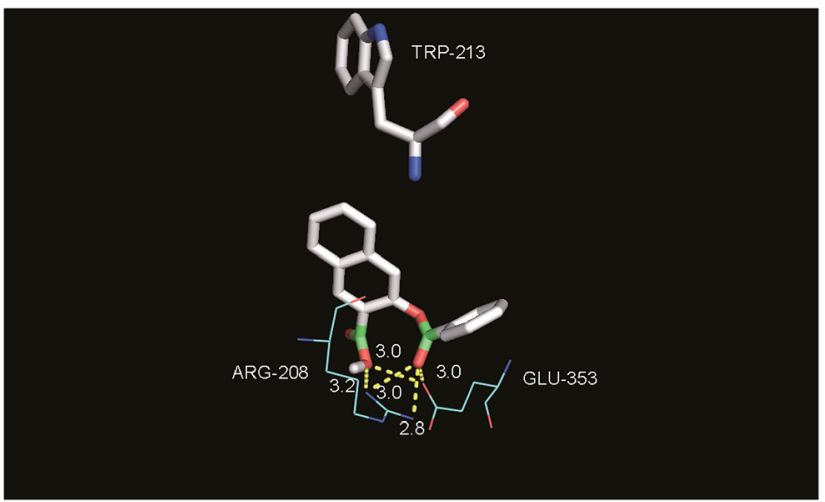

Fig. 13 View of the binding of 3 a to BSA in Site I of subdomain IIA.

Table 2 Quantum yields for visible light $(\lambda=419 \mathrm{~nm})$ induced $\mathrm{CO}$ release from $2 a$ under various conditions under air

\begin{tabular}{ll}
\hline Conditions $(\mathrm{pH}=7.4)$ & Quantum yield \\
\hline $\mathrm{CH}_{3} \mathrm{CN}$ & $0.007(3)$ \\
$1: 1$ DMSO $:$ TRIS & $0.006(3)$ \\
$1: 1$ DMSO $:$ PBS & $0.010(3)$ \\
$4 \%$ DMSO $:$ PBS + CTAB & $0.0063(1)$ \\
$\mathrm{BSA}(40$ eq.) in $3.3 \%$ DMSO $:$ TRIS & $0.0006(1)$ \\
{$\left[(\right.$ bpy $\left.) \mathrm{Zn}\left(2 \mathbf{a}^{-}\right)\right] \mathrm{ClO}_{4}$ in $1: 1$ DMSO $: \mathrm{H}_{2} \mathrm{O}$} & $0.017(1)$
\end{tabular}

decreased the binding affinity of $\mathbf{2 a}$ for BSA to a value similar to that observed for the zinc complex $\left[(\mathrm{bpy}) \mathrm{Zn}\left(\mathbf{2 a}^{-}\right)\right] \mathrm{ClO}_{4}$ (4) (Table 1).

\section{CO release reactivity}

With an understanding of the solution properties of $2 \mathbf{a}$ under a variety of aqueous conditions, we next examined the efficiency of the visible light-induced CO release reaction (Scheme 1) under the conditions listed in Table 2. The quantum yields for $\mathrm{CO}$ release from $2 \mathrm{a} / 2 \mathrm{a}^{-}$ranges from 0.006 to 0.010 , with binding of 2a to BSA producing a $\sim 10$-fold lower quantum yield than that found for the free molecule in 1:1 DMSO : buffer or $\mathrm{CH}_{3} \mathrm{CN}$ solutions. Thus the reaction quantum yields found for 2 a do not change appreciably as a function of solvent. This is similar to the quantum yields found for $\mathrm{CO}$ release from a $\mathrm{Zn}$ (II) 3-hydroxyflavone complex wherein a change of solvent from $\mathrm{CH}_{3} \mathrm{CN}$ to $\mathrm{H}_{2} \mathrm{O}$ : DMSO $(1: 1)$ resulted in only a two-fold change in reaction quantum yield.$^{67}$ For $2 \mathrm{a}^{-}$the presence of $\mathrm{Zn}^{2+}$ in the form of the $\left[(\mathrm{bpy}) \mathrm{Zn}\left(2 \mathbf{a}^{-}\right)\right] \mathrm{ClO}_{4}$ (4) complex produces a slightly higher quantum yield $(0.017(1))$. We note that the quantum yields for CO release obtained for $\mathbf{2 a}$ under all of these conditions are at least five-fold greater than those of the BODIPY derivatives 1a and $\mathbf{1 b}$ under aerobic conditions. ${ }^{39}$

\section{Discussion and conclusions}

The development of carbon monoxide releasing molecules (CORMs) for therapeutic applications is an area of significant current interest. ${ }^{2-8,15,16}$ While the majority of CORMs evaluated to date are based on a metal carbonyl moiety as the CO release unit, challenges regarding incorporation of drug-like structural components, combined with concerns about the possible side reactivity and toxicity of such structures in therapeutic applications, have hampered further development. Metal-free COreleasing molecules, particularly those that can be controlled in terms of the timing and location of CO release, are attractive as such moieties are likely to be more amenable to standard medicinal chemistry approaches. ${ }^{4}$ In this regard, CO-releasing organic molecules that can be triggered by visible light are of particular current interest. Two novel metal-free, visible lightinduced $\mathrm{CO}$ release structural motifs have been recently reported. These are based on BODIPY $(\mathbf{1 a} / \mathbf{1} \mathbf{b})^{39}$ and extended flavonol (2a-d) $)^{42}$-type structural motifs. Both types of compounds offer attractive features, including low-to-medium toxicity and strong fluorescent emission features that enable tracking in a biological environment. An additional advantage of the BODIPYbased compounds is the structural tunability that enables the use of light of $>700 \mathrm{~nm}$ to induce CO release. Weaknesses of the BODIPY motif include the requirement of anaerobic conditions to achieve quantitative $\mathrm{CO}$ release and the lack of full characterization and toxicity evaluation of the $\mathrm{CO}$ release products. The extended flavonol motif offers several notable features that are desirable toward the further development of visible light induced CO release compounds. We previously reported the structural tunability of the flavonol motif in 2a-d that enables modulation of the wavelength of light that can be used to induce CO release as well as tune the quantum yield for this reaction. ${ }^{42}$ We discovered that one derivative (2d) offers the opportunity to access anaerobic CO release reactivity. Another distinct advantage of the framework in $2 \mathbf{a}$ is the ease of synthesis, which involves a one-pot reaction from commercially available starting materials.

In this contribution, we outline details of the solution properties of $\mathbf{2 a}$ in aqueous buffer environments at physiological $\mathrm{pH}$ (7.4) and in the presence of charged or biologically relevant molecules. Our results indicate that 2 a can undergo partial ionization to $\mathbf{2 \mathbf { a } ^ { - }}$ under certain conditions (e.g., in PBS buffer or in the presence of a cationic surfactant). We have found that the presence of $\mathrm{Zn}^{2+}$ will enhance the quantum yield for CO release from 2a. Overall this knowledge is important with regard to using $\mathbf{2 a}$ in biological environments.

As we have described herein, compound $2 \mathbf{a}$ is the most reactive metal-free photoCORM motif reported to date under a variety of conditions. The ease of synthesis and structural modification of the extended flavonol framework of $2 \mathbf{a}$, coupled with the reliability of the molecule in terms of visible light induced CO release reactivity under aqueous conditions, makes it especially well-suited for the further development of a family of CO-releasing molecules with modifications to enhance biological properties, functionality, and targeting. Such efforts are currently underway in our laboratory.

\section{Acknowledgements}

We thank the US National Science Foundation (CHE-1301092 to LMB; CHE-1429195 for Bruker Avance III HD Ascend-500 spectrometer) for funding. 


\section{References}

1 G. Kikuchi, T. Yoshida and M. Noguchi, Biochem. Biophys. Res. Commun., 2005, 338, 558.

2 R. Motterlini and L. E. Otterbein, Nat. Rev. Drug Discovery, 2010, 9, 728.

3 C. Steiger, C. Hermann and L. Meinel, Eur. J. Pharm. Biopharm., 2016, DOI: /10.1016/j.ejpb.2016.11.002.

4 X. Ji, K. Damera, Y. Zheng, B. Yu, L. E. Otterbein and B. Wang, J. Pharm. Sci., 2016, 105, 406.

5 C. Szabo, Nat. Rev. Drug Discovery, 2016, 15, 185.

6 K. Nakahira and A. M. K. Choi, Am. J. Physiol.: Lung Cell. Mol. Physiol., 2015, 309, L1387.

7 O. Sulaieva and J. L. Wallace, Curr. Opin. Pharmacol., 2015, $25,1$.

8 C. C. Ramão, W. A. Blattler, J. D. Seixas and G. J. L. Bernardes, Chem. Soc. Rev., 2012, 41, 3571.

9 A. Belhaj, Role of Carbon Monoxide in the Ex Vivo Lung Perfusion Reconditioning, in ClinicalTrials.Gov, University Hospital of Mont-Godinne, National Library of Medicine (US), Bethesda (MD), 2014, present. NLM Identifier: NCT02032082.

10 I. O. Rosas, Study of Inhaled Carbon Monoxide to Treat Idiopathic Pulmonary Fibrosis, in ClinicalTrials.Gov, National Library of Medicine (US), Bethesda (MD), 2010, present. NLM Identifier: NCT01214187.

11 Weill Medical College of Cornell University, Safety Study of Inhaled Carbon Monoxide to Treat Acute Respiratory Distress Syndrome (ARDS), in ClinicalTrials.Gov, National Library of Medicine (US), Bethesda (MD), 2015, present. NLM Identifier: NCT02425579.

12 Medical University of South Carolina, Carbon Monoxide Saturated Medium for Islet Isolation, in ClinicalTrials.Gov, National Library of Medicine (US), Bethesda (MD), 2015, present. NLM Identifier: NCT02567240.

13 R. Machado, Carbon Monoxide Therapy for Severe Pulmonary Arterial Hypertension ( $\mathrm{CO}$ in $\mathrm{PAH}$ ), in ClinicalTrials.Gov, University of Illinois at Chicago, National Library of Medicine (US), Bethesda (MD), 2012, present. NLM Identifier: NCT01523548.

14 C. Wang, Daping Hospital and the Research Institute of Surgery of the Third Military Medical University, The Safety and Adverse Reaction Study of Neonatal to Inhaled Carbon Monoxide (CO), in ClinicalTrials.Gov, National Library of Medicine (US). Bethesda (MD), 2013, present. NLM Identifier: NCT01818843.

15 F. Zobi, Future Med. Chem., 2013, 5, 175.

16 U. Schatzschneider, Br. J. Pharmacol., 2015, 172, 1638.

17 B. E. Mann, Top. Organomet. Chem., 2010, 32, 247.

18 I. Chakraborty, S. J. Carrington and P. K. Mascharak, Acc. Chem. Res., 2014, 47, 2603.

19 M. A. Gonzales and P. K. Mascharak, J. Inorg. Biochem., 2014, 133, 127.

20 S. J. Carrington, I. Chakraborty and P. K. Mascharak, Dalton Trans., 2015, 44, 13828.
21 R. Mede, M. Klein, R. A. Claus, S. Krieck, S. Quickert, H. Görls, U. Neugebauer, M. Schmitt, G. Gessner, S. H. Heinemann, J. Popp, M. Bauer and M. Westerhausen, Inorg. Chem., 2016, 55, 104.

22 R. Mede, J. Traber, M. Klein, H. Görls, G. Gessner, P. Hoffmann, M. Schmitt, J. Popp, S. H. Heinemann, U. Neugebauer and M. Westerhausen, Dalton Trans., 2017, 46, 1684.

23 M. Tinajero-Trejo, N. Rana, C. Nagel, H. E. Jesse, T. W. Smith, L. K. Wareham, M. Hippler, U. Schatzschneider and R. K. Poole, Antioxid. Redox Signaling, 2016, 24, 765.

24 A. E. Pierri, A. Pallaoro, G. Wu and P. C. Ford, J. Am. Chem. Soc., 2012, 134, 18197.

25 M. A. Wright and J. A. Wright, Dalton Trans., 2016, 45, 6801. 26 E. Stamellou, D. Storz, S. Botov, E. Ntasis, J. Wedel, S. Sollazzo, B. K. Krämer, W. van Son, M. Seelen, G. H. Schmalz, A. Schmidt, M. Hafner and B. A. Yard, Redox Biol., 2014, 2, 739.

27 S. Romanski, E. Stamellou, J. T. Jaraba, D. Storz, B. K. Krämer, M. Hafner, S. Amslinger, H. G. Schmalz and B. A. Yard, Free Radical Biol. Med., 2013, 65, 78.

28 S. Romanski, B. Kraus, M. Guttentag, W. Schlundt, H. Rücker, A. Adler, J. M. Neudörfl, R. Alberto, S. Amslinger and H. G. Schmalz, Dalton Trans., 2012, 41, 13862.

29 S. Romanski, B. Kraus, U. Schatzschneider, J. M. Neudörfl, S. Amslinger and H. G. Schmalz, Angew. Chem., Int. Ed., 2011, 50, 4038.

30 H. Meyer, M. Brenner, S. P. Höfert, T.-O. Knedel, P. C. Kunz, A. M. Schmidt, A. Hamacher, M. U. Kassack and C. Janiak, Dalton Trans., 2016, 45, 7605.

31 P. C. Kunz, H. Meyer, J. Barthel, S. Sollazzo, A. M. Schmidt and C. Janiak, Chem. Commun., 2013, 49, 4896.

32 H. Meyer, F. Winkler, P. Kunz, A. M. Schmidt, A. Hamacher, M. U. Kassack and C. Janiak, Inorg. Chem., 2015, 54, 11236.

33 T. Santos-Silva, A. Mukhopadhyay, J. D. Seixas, G. J. L. Bernardes, C. C. Romão and M. J. Romão, J. Am. Chem. Soc., 2011, 133, 1192.

34 M. Chaves-Ferreira, I. S. Albuquerque, D. Matak-Vinkovic, A. C. Coelho, S. M. Carvalho, L. M. Saraiva, C. C. Ramão and G. J. L. Bernardes, Angew. Chem., Int. Ed., 2015, 54, 1172.

35 A. A. Petruk, A. Vergara, D. Marasco, D. Bikiel, F. Doctorovich, D. A. Estrin and A. Merlino, Inorg. Chem., 2014, 53, 10456.

36 J. D. Seixas, A. Mukhopadhyay, T. Santos-Silva, L. E. Otterbein, D. J. Gallo, S. S. Rodrigues, B. H. Guerreiro, A. M. L. Goncalves, N. Penacho, A. R. Marques, A. C. Coelho, P. M. Reis, M. J. Romão and C. C. Romão, Dalton Trans., 2013, 42, 5985.

37 X. Ji, C. Zhou, K. Ji, R. E. Aghoghovbia, Z. Pan, V. Chittavong, B. Ke and B. Wang, Angew. Chem., Int. Ed. Engl., 2016, 55, 15846.

38 D. Z. Wang, E. Viennois, K. Ji, K. Damera, A. Draganov, Y. Q. Zheng, C. Dai, D. Merlin and B. Wang, Chem. Commun., 2014, 50, 15890. 
39 E. Palao, T. Slanina, L. Muchová, T. Solomek, L. Vítek and P. Klán, J. Am. Chem. Soc., 2016, 138, 126.

40 P. Peng, C. Wang, Z. Shi, V. K. Johns, L. Ma, J. Oyer, A. Copik, R. Igarashi and Y. Liao, Org. Biomol. Chem., 2013, 11, 6671.

41 L. A. P. Antony, T. Slanina, P. Sebej, T. Solomek and P. Klán, Org. Lett., 2013, 15, 4552.

42 S. N. Anderson, J. M. Richards, H. J. Esquer, A. D. Benninghoff, A. M. Arif and L. M. Berreau, ChemistryOpen, 2015, 4, 590.

43 S. Fetzner, Appl. Environ. Microbiol., 2012, 78, 2505.

44 S. N. Anderson, M. T. Larson and L. M. Berreau, Dalton Trans., 2016, 45, 14570.

45 Y. A. Dávila, M. I. Sancho, M. C. Almandoz and S. E. Blanco, J. Chem. Eng. Data, 2013, 58, 1706.

46 K. Grubel, S. Saraf, S. N. Anderson, B. J. Laughlin, R. C. Smith, A. M Arif and L. M. Berreau, Inorg. Chim. Acta, 2012, 407, 91.

47 H. J. Kuhn, S. E. Braslavsky and R. Schmidt, Pure Appl. Chem., 2004, 76, 2105.

48 C. G. Hatchard and C. A. Parker, Proc. R. Soc. London, Ser. A, 1956, 235, 518.

49 O. Trott and A. J. Olson, J. Comput. Chem., 2010, 31, 455.

50 B. Dick and N. P. Ernsting, J. Phys. Chem., 1987, 91, 4261.

51 R. Lakowicz, Principles of Fluorescence Spectroscopy, Kluwer Academic/Plenum Publishers, New York, 2nd edn, 1999.

52 S. L. Sorenson, M. Popova, A. M. Arif, and L. M. Berreau, submitted for publication.
53 M. Sarkar and P. K. Sengupta, Chem. Phys. Lett., 1991, 179, 68.

54 J. Guharay, B. Sengupta and P. K. Sengupta, Proteins, 2001, 43, 75.

55 A. Sytnik and I. Litvinyuk, Proc. Natl. Acad. Sci. U. S. A., 1996, 93, 12959.

56 J. Xiao, M. Suzuki, X. Jiang, X. Chen, K. Yamamoto, F. Ren and M. Xu, J. Agric. Food Chem., 2008, 56, 2350.

57 E.-H. Liu, L.-W. Qi and P. Li, Molecules, 2010, 15, 9092.

58 B. Mishra, A. Barik, K. I. Priyadarsini and H. Mohan, J. Chem. Sci., 2005, 117, 641.

59 M.-X. Xie, M. Long, Y. Liu, C. Qin and Y.-D. Wang, Biochim. Biophys. Acta, 2006, 1760, 1184.

60 S. Pal and C. Saha, J. Biomol. Struct. Dyn., 2014, 32, 1132.

61 B. Liu, Y. Pang, R. Bouhenni, E. Duah, S. Paruchuri and L. McDonald, Chem. Commun., 2015, 51, 11060.

62 J. Dai, T. Zou, L. Wang, Y. Zhang and Y. Liu, Luminescence, 2014, 29, 1154.

63 S. Pal, C. Saha, M. Hossain, S. K. Dey and G. S. Kumar, PLoS One, 2012, 7, e43321.

64 A. Sulkowska, B. Bojko, J. Rownicka and W. W. Sulkowski, Biopolymers, 2006, 81, 464.

65 K. Yamasaki, V. T. G. Chuang, T. Maruyama and M. Otagiri, Biochim. Biophys. Acta, 2013, 1830, 5435.

66 F. Zsila, Mol. Pharmaceutics, 2013, 10, 1668.

67 S. N. Anderson, M. Noble, K. Grubel, B. Marshall, A. M. Arif and L. M. Berreau, J. Coord. Chem., 2014, 67, 4061-4075. 